\title{
When the Forest Does Not Sing Anymore. Cuerpo- territorio Approach of Amazonian Indigenous Women to the Concepts of Conflict and Violence
}

\author{
Diana Paola Garcés-Amaya \\ Institute of Migrations, University of Granada (Spain)
}

Based on an ethnographic study, this paper investigates the process of indigenous women in Colombia who are members of the organisation OPIAC and underpins the narratives and situated knowledge they propose in order to understand what conflict and violence mean from their personal and community experiences. The research identifies how cuerpo-territorio is an epistemological starting point that emerges from reinterpreting their worldviews and helps explain the ontological relationship between body, territory, identity, and spirituality. Unpacking this premise, the cuerpo-territorio approach to peace and conflict implies a more reflective and holistic understanding, including other dimensions and ethos. Dispossession of ancestral lands, exploitation of terri- tory, forced displacement and violence against women constitute personal and collective harms that create imbalance and disharmony. Finally, the analysis states that by adopting intersectional and decolonial approaches in critical peace studies, we can shed light on what is silenced by dominant approaches and challenge the limits of institutional and anthropocentric conceptions. Likewise, this "inclusion" must nevertheless be accompanied by material conditions since, despite the signing of the Havana Peace Agreement, indigenous peoples remain under the crossfire of armed actors in their ancestral territories.

Keywords: conflict, war, indigenous women, cuerpo-territorio, relational ontology.

I n 2016, the Colombian government signed the Havana Peace Agreement with the Revolutionary Armed Forces of Colombia guerrillas (FARC acronym in Spanish from Fuerzas Armadas Revolucionarias de Colombiana), hoping to end more than 60 years of armed conflict. The agreement included political and agricultural reforms to address historical inequalities and open the way to 
social justice. At the same time, it was also important the institutional framework created to investigate the crimes committed and the responsibilities of the armed actors through the Special Jurisdiction for Peace (Jurisdicción Especial de la Paz).

Undoubtedly, the General Agreement to End the Conflict was groundbreaking because of the participation of victims, the special chapter on symbolic reparations for victims within the agreements, and the creation of a Gender Sub-commission. However, five years after its signature, Colombia is facing an increase in levels of violence due to the rearmament of dissident groups, disputes between armed groups over territorial and social control in rural areas following the FARC's withdrawal, and the lack of political will on the part of the current government to implement the agreements on political participation and agricultural development.

Historically affected regions continue to be the most brutal hit in this postconflict phase. Dispossession of ancestral lands forced displacement, and the assassination of social leaders have shown that peace and guarantees of nonrepetition for victims are still halfway. At the same time, the war continues to be mobilised as a discursive resource by political and economic elites.

Despite this panorama, at the territorial level, there are a diversity of peacebuilding initiatives characterised as local alternatives based on the needs and contexts of peasant, afro-descendant, indigenous, and popular collectives, who appear to be the "Others" of modernity and the national-building project. These initiatives coincide in: First, incorporate dissident perspectives on both neoliberal and Western-modern approaches to peace. Second, they focus on the need for the durability of peace processes by challenging historical power structures. Finally, they mobilise subaltern knowledge as proposals for living together among human beings and in the territory, thinking about peace beyond the absence of war.

This article aims to make visible the critical peace and conflict approaches of indigenous women's collectives in the Amazon as subaltern epistemologies and holistic practices for building local(s) peace(s). They advocate in response to neoliberal, technocratic, centralist, top-down imposed peace by focusing on the importance of territorial approaches and propositions grounded on situated knowledge and epistemic privilege. The article draws on the experiences of indigenous women who are part of the Organisation of Indigenous Peoples of the Colombian Amazon (OPIAC acronym in Spanish from Organización de Pueblos Indígenas de la Amazonía Colombiana) and examines the narratives that these women have proposed in their collective and pedagogical processes about violence and conflict from ethnographic fieldwork. This paper also engages in historical memory and reconstruction of social tissue that these women lead, thus, elaborates on the genealogy cuerpo-territorio as a condition of peacebuilding and finally states the importance of considering intersectional-decolonial approaches counting on the collective spiritual dimension.

The article is divided into three substantive parts. The first part introduces feminist and local approaches to peace and conflict studies and outlines a theoretical framework that might explain the process of indigenous women by showing how they participate in the battles for interpretation and signification. 
The second part offers a context of the participants in the research, drawing attention to the milestones of Indigenous women's coordination and the steps taken to achieve autonomy and recognition. The third part analyses the approach and understanding of the conflict by focusing on the relational ontology of cuerpo-territorio and elaborates on personal, collective, and territorial harms.

\section{UNDERSTANDING CONFLICT AND PEACE FROM THE MARGINS}

Several scholarly works have recovered previously marginalised perspectives by including epistemological contributions and empirical and social processes in recent years. In this case, the rise of critical feminist work (Mirón, 2009; Reardon, 2010; Díaz, 2012; McLeod and O'Reilly, 2019) calling for the inclusion of women's perspectives and experiences, as well as the power structures that compromise these exclusions and silences, is striking. That is also the case of the growing local approach (Mac, 2015; Björkdahl and Höglund, 2013), which claims the importance of bottom-up, decentralised, experience-based knowledge as the basis for structural peacebuilding. Both perspectives are critical of monolithic liberal/neo-liberal peace approaches (Mac, 2010) and state-centrist analyses of conflict resolution, and yet, as Sabaratnam (2013) noted, the critical approaches fail to displace the eurocentrism discourses and the depiction of the local as an "Other", as the exotic of the equation.

The article draws on these premises to understand the role of indigenous Amazonian women's discourses and interpretive frames in the contemporary emergence of counter-narratives to war, focusing on how the floating signifiers of "conflict" and "peace" acquire connotations in different contexts, shedding light on how this organisation is part of the forces and struggles to fix the meaning (Rodríguez, 2019). Moreover, the analysis highlights how central their propositions are to understanding the complexity of historical violence and inequalities and the disproportionate harm that dispossession of ancestral territories and militarism have entailed. However, despite the contribution of the approaches mentioned above, it is also necessary to adopt an intersectional and holistic view as indigenous women experience the consubstantiality of oppressions (Anzaldúa, 1989; Lugones, 2008). This implies that they have a special relationship with the territory, the collectivity, and the spirituality. Therefore, asking Indigenous women not to define themselves primarily in terms of a mixed collective and against racism is to ignore the specific history of Indigenous women and nations. In other words, it implies erasing Indigenous feminist identity (Gargallo, 2012: 12).

It is worth noting that these interpretations of war and peace are characterised as decolonial, insofar as liberal peace has sought to erase the traces of colonialism and coloniality of power that are part of the construction of nation-states (Rodríguez, 2019). Which, on the one hand, reproduces biopolitical and ontological hierarchies to dominate bodies, their labour force, their sexuality, and their territory (Quijano, 2000), while at the same time imprinting symbolic 
violence by hierarchising knowledge (about war, peace, development, social justice), and marginalising and silencing alternative narratives.

Furthermore, and following Blázquez (2010), I recognise that the indigenous women of the OPIAC have claimed an epistemic privilege where the place they occupy as subalterns becomes a resource of knowledge: "the life and condition of women provide them with a different optic to recognise social reality" (Blázquez, 2010: 30). It is not an essentialist stance that assumes an embodied nature in certain bodies; on the contrary, it is their situated experience that becomes a privileged place to read oppression and, consequently, legitimate to denunciate it. The perspective here assumed recognises that these discourses have been the product of resistance and reconstruction of the social tissue (going back inside) where cultures reinvent themselves to survive through words and reflection with wise elderly members.

From the crossroads of feminist and decolonial theories on peacebuilding, this article recognises these women as political actors, given that this is one of the weaknesses of critical peace studies (McLeod and O'Reilly, 2019). Secondly, in this research, we understand the OPIAC as part of a collective process of meaning production immersed in the struggles to define and re-signify "peace" and in the "battle for memory" (Escobar et al., 2001: 19).

\section{THE PROCESS OF THE AMAZONIAN WOMEN OF THE OPIAC}

The indigenous women who are the protagonists of this article belong to OPIAC, one of the national indigenous organisations in Colombia that articulates localbased affiliates to bring their demands to the government levels and influences the arenas in which Amazonian peoples are affected. It is worth noting that this organisation is a mixed process that declares the need for struggles and resistance as a collective subject, but as such also recognises the specificities of indigenous women; the historical exclusions and loss of material and symbolic power as a result of patriarchal entanglement or gender coloniality (Lugones, 2008).

In response to the above, indigenous women have taken the initiative to gather together by creating the Coordinación de Mujer, Niñez y Familia de la OPIAC since 2012. However, this does not mean that Amazonian women have not been protagonists of collective struggles before (with historical leaders of the movement, healers, and wise elder women), but the creation of a "women's office" meant a break with the "traditional" way in which women were part of the movement. The institutionalisation of a Women Coordination provided strategic opportunities to create alliance scenarios with their male colleagues and different international institutions. It made it possible to address specific issues such as gender-based violence, sexist practices within organisational processes, the impact of war on their bodies and lives, which were previously invisible in the political discourse of the OPIAC (interview with the coordinator of the women's office, 2015). In addition, they have gained political autonomy to negotiate public policies, national development plans, peace-related programmes, and protection mechanisms in the face of conflict and forced displacement within 
their organisation and with the State (interview with the wise elder woman of the process, 2015). They are also actors who redefine their cosmovision and philosophies and enhance the spaces of fogón ${ }^{1}$ and $c h a g r a^{2}$ traditionally allocated to women.

This relative degree of autonomy and recognition was made possible by political and discursive openings at the state level that led to a favourable political opportunity structure (Tarrow, 2004), in other words, to the attainment of visibility and recognition "outwards". This cycle of political opportunities began with the participation of OPIAC women in the shadow report submitted to the 37th session of CEDAW in 2007 and the series of documents of the Working Group on "Women and Armed Conflict" led by feminist NGOs. From then on, they participated in the monitoring and follow-up of the State's actions to comply with the Constitutional Court ${ }^{3}$ orders regarding the protection of indigenous women victims of conflict and forced displacement.

Certain negotiation scenarios with the State had increasingly tended to incorporate - even formally and with great difficulty - the so-called "ethnic differentiated approach", which is particularly evident with the change of government in 2010 when Juan Manuel Santos took office. The militaristic discourse of the two previous governments gave way to the consolidation of a legal framework for transitional justice with a system of alliances and coalitions in the Congress of the Republic. The government approved the Victims and Land Restitution Law (2011) and initiated the peace process with the FARC guerrillas that finally came to fruition with the Havana Agreements (2016). The latter included hearings for victims of the war and encouraged communities, social organisations, and universities to open spaces to discuss the end of the conflict. ${ }^{4}$ All of this has enabled indigenous women to mobilise their peace agenda and gain ground, albeit limited, in institutional politics.

In assessing the state's response, women highlight the high institutional shortcomings, both in terms of attention to indigenous women in the policy of attention and reparation to victims and the introduction of gender and

1 Spaces for food preparation and where women gather together.

2 It refers to food production gardens developed through seasonal rotations and caring for the soil. It includes burning, sowing, and harvesting crops to ensure food security and sovereignty. It is also one of the central scenarios for the transmission of worldview.

3 I refer to Auto 092 of 2008, the purpose of which is to protect the fundamental rights of women displaced by armed conflict and to prevent the disproportionate gender impact of war and forced displacement. It directs the State to create thirteen programmes, including Prevention of Disproportionate Impact displacement, Prevention of Sexual Violence against Women, Prevention of Domestic and Communal Violence, Access to land ownership and Protection of Indigenous Women's Rights.

4 In this case, the Peasant Reserve Zones (ZRC acronym in Spanish from Zonas de Reserva Campesina), the Peace Laboratories initiatives, the Mingas of the indigenous peoples, and the local councils of the Afro-descendant peoples are of great political relevance. 
ethnic approach. Women have denounced the low political will to negotiate and implement what has been agreed: Officials without the capacity to make decisions, the postponement of meetings and delays in the implementation of agreements, the unavailability or "tight" budget as an argument from institutions, the demand to standardise criteria and actions for such diverse peoples and political processes, and the marked tendency of some institutions to convene meetings and take for granted their responsibility beyond the implementation of programmes or projects (interview with a social leader, 2017).

Nevertheless, and in parallel with the difficulties and barriers described above, Coordinación de Mujer, Niñez y Familia de la OPIAC is initiating a process of internal and bottom-up empowerment focused on grassroots organisations and initiatives in the six regions that make up Colombian Amazon. Since 2015, the first "sting in the basket" was formulating the strategic action plans to guarantee the Rights of Amazonian Indigenous Women ${ }^{5}$ and a Mandate that summarised the needs and demands of the daughters of sweet yucca, tobacco, yagé, yuruparí and ancestral wisdom. These documents systematised the situation of women as a result of the armed conflict and called for greater participation of the women's process in the government and the grassroots and national organisations of the indigenous movement.

From then on, these actors managed to gain legitimacy (within their movement and in the eyes of the institutions) to be recognised as autonomous actors and leaders of their processes, making visible their work for the preservation and survival of indigenous peoples. The most important achievement was establishing the School for the Empowerment of Amazonian Women, which combined participatory research, political training, and historical memory exercises. It addressed issues such as peacebuilding, psychosocial and spiritual reparations, food sovereignty, and women's leadership.

I have drawn on the reflections that emerged in these spaces of mutual empowerment to develop this article based on the participants' categories. I conducted an ethnography embedded in a larger project that I carried out from 2015 to 2017, accompanying the Indigenous Women's School and the OPIAC process in Bogotá, Florencia, Puerto Leguizamo, San José del Guaviare, and Puerto Nariño. This space included participants from different Amazonian peoples, among them Piratapuyo, Piapoco, Puinave, Desana, Curripaco, Cubeo, Kamentsa, Uitoto, Murui-Muinane Miraña, Macuna, Koreguaje, Ticuna, Cocama, Yanacona. The ethnography was developed through workshop facilitation, direct active and passive observations, and semi-structured and in-depth interviews. This experience accounts for the narratives of peace, the resistances to war

5 "Each of the six departments that make up Colombian Amazon outlined an action plan that grassroots organisation validated. These departments identified ten areas of action that women prioritised: Health, education, political participation, culture, right to territory, food sovereignty and autonomy, housing and sanitation, conditions for those living in urban centres, income generation. In addition, established actions regarding the violence within families and communities and in the context of armed conflict" (Coordinación de Mujer, Niñez y Familia de la OPIAC, 2015: 12). 
and historical memory based on their "uses and customs". The focus was on indigenous women's spiritual healing and leadership processes in their territories and grassroots organisations. Along with the ethnography, the research analysed documents produced by the organisation (including proclamations, internal and external reports, audio-visual archives).

\section{CUERPO- TERRITORIO STANDPOINT}

The ontological and epistemic proposal of cuerpo-territorio as such is not exclusive to the OPIAC women's process, as some decolonial feminist thinkers have elaborate on it in Latin America (as in the case of activist Cabnal (2010)) and the approaches of human geography that perform cross-cultural transcription (Sweet and Ortiz, 2017; Marchese, 2019; Haesbaert, 2020; Zaragocin and Caretta, 2020). However, what is certain is that none of this work has focused on exploring how this proposal serves to understand the meaning of conflict in the lives of indigenous women. Furthermore, this proposal is the one that best succeeds in framing the worldview and reasoning that emerge from their knowledge and experience. Cuerpo-territorio as a relational ontology characterises by the holistic and integrated way of understanding conflict and peacebuilding.

The concept emerges from a diametrically critical premise of the Western understanding of the separation of body and earth (and spirit). The separation of the individual from his environment (Cartesian body/mind dichotomy and nature/culture divide), the hierarchisation of the former as lord and master through a relationship of exploitation of the animate and inanimate beings that inhabit the earth. On the contrary, in the philosophy of the Amazonian peoples, the body is inscribed (beyond a medical or biological fact) in an order of signification existentially linked to the ancestors' territory, the cosmic universe. They all represent indissoluble entities that acquire meaning through the vindication of cultural identity. This is what Púa (2010) has called the Amerindian ethic and ecosophy based on care and responsibility.

Body and territory are subjects of wisdom with a history, a memory and, above all, closely embedded in the spiritual and collective dimensions. Their relationship is based on the principle of complementarity, so that whatever affects one of these dimensions affects the others and has consequences for the balance of the whole; spirituality — sacredness - life - death. The territory is a living entity. The Amazon River is the metaphor of life. Its movement over the ancestral land and the irrigation of the harvest on its way represents the power of life. There coexist human beings, animals, and the spirits of the ancestors, tobacco, sweet yucca, and yopo. The territory is the extension of the body and the culture. It is the beginning and the end.

A first approximation of how the women of OPIAC understand conflict and violence relates to this inseparability of body-territory-spirit. Thus, this is not limited to the direct violence of the armed confrontation between the government, the guerrillas, the paramilitaries, and the violence experienced in everyday life within Western society. Amazonian women thus identify impoverishment, the 
imposition of neoliberal and extractivist models of development, state centralism, racism and discrimination against indigenous peoples, and the gender-based violence that indigenous women experience in their communities and families as conflictual facts for the survival of their peoples because:

They exacerbate and deepen discrimination against us because we are women and indigenous, for this reason, we consider that they are multiple and intertwined in our lives producing great suffering for us (interview with the coordinator of the women's office, 2015).

This shows that the conflict expresses itself as a malaise of the spirit and the territory. Moreover, it generates inestimable collective damage since it implies the disappearance of their cultures, of their harmony, since their subjectivity and identity are based on the collective existence and the connexion with the ancestral territory.

In this case, war, violence, and power matrices show how they are embodied, felt, and experienced in specific bodies and produce specific affectations. Therefore, another way to understand the conflict from the perspective of Amazonian women could be through the concept of the continuum of violence; to account for a spectrum of intersectional and different forms of violence with different intensities, considering the multiple and widespread affectations as women and as indigenous peoples. For this reason, this analysis shares Femenías' assessment that subjects in subaltern conditions have more directly experienced an intertwining of types of violence which produce a standpoint "to argue the defence and claim just response" (2011: 48). This help to explain why, at the centre of indigenous women's demands, is the struggle against the dispossession and exploitation of their territories, the various forms of violence against their bodies-as women and collective subjects-and for the survival of their peoples.

The latter resembles feminist approaches to conflict and their critical view of negative peace (McLeod and O'Reilly, 2019). Likewise, it contests the assumed tension between the goals of gender equality and local ownership (Gordon et al. 2015) or communitarian culture (Young, 1990), as the core question lies in how gender and racism against indigenous collectives produce conditions of subalternity in times of war as in times of peace within global inequalities. Thus, the intersectionality proposed in their discourses challenges the material and symbolic structures of coloniality of power that still exist in post-conflict and transitional scenarios.

In what follows, I outline some of the central ideas that the Amazon women of OPIAC have proposed in their processes of education and healing, which help to understand, first from the territorial dimension and then from the corporal dimension, what the impacts and their collective, personal and spiritual consequences are.

\section{The Ancestral and Collective Territory}

Historically, land has always been linked to the struggles of social movements, especially those of peasant, indigenous and afro-descendant collectives. In this 
sense, the territory has been one of the axes of the most urgent demands for access to livelihoods (food security and sovereignty) and as the scenario in which alternative development projects and alternative ways of life are possible. In this case, the use of the term territory emphasises the idea of space as a social product. In this regard, Santos' (2000) approach is striking in acknowledge how space is lived, especially for communities that privilege affective and symbolic values over use-value. Secondly, to recall the concept of "ancestral territory" as indigenous peoples have referred to the place they have historically shared with other beings, but where they have developed their culture, their cosmovision and where it represents their individual and collective existence.

Despite their diversity, the origin myths ${ }^{6}$ of the Amazonian peoples coincide in their depiction of the earth as mother, home, and shelter (interview with wise elder woman, 2017). Moreover, the designation ${ }^{7}$ of these peoples evidences their connection with the earth as well as the different elements found in their territories that form their collective identity.

The ancestral territory is the scenario in which the entire existence of the present people takes place, and where the relationship with the ancestors is first possible: Life and death (births, the sowing of the placenta of newborns, and the burial of deceased grandparents), rites and ceremonies, marriages, the sowing and harvesting of chagras, hunting and fishing, the collection of traditional medicine, and the production of knowledge in the talking circles in the malocas. ${ }^{8}$ Because of this immeasurable importance, then, the damage to territory and what lives in it is collective and cultural, which was manifested by the elderly members during the talking and mambeo circles $^{9}$ in the maloca and the historical memory exercises.

In particular, they have referred to different episodes that have undermined harmony. First, rubber plantations date back to the beginning of the 20th century. They manifest the imposition of a rubber-based extractive economy from the dispossession of land and the enslavement of the original indigenous communities as free labour (Coordinación de Mujer, Niñez y Familia de la OPIAC, 2015a: 15). Subsequently, with the process of "colonisation" led by the government, the agricultural frontier advanced, clearing the virgin forest to make way for the hegemonic vision of development that ended with the first oil boom in 1963. The second phase of territorial damage is related to the geostrategic role that the Amazon played in the armed conflict. The region

6 It means "the ancient word", it is the wisdom passed down orally from generation to generation and is part of the Special Jurisdiction of the peoples.

7 For example, Makuna means "children of the water anaconda", Siona "the people of Chagra", Koreguaje "the people of the land", Bora "the people of tobacco, coca, sweet cassava" and Wanano "the people of water".

8 The malocas are the axis of ceremonial and ritual life.

9 It is a ritual form of consuming the coca leaf in which the traditional authorities of the community intervene, exchange words, share thoughts and direct decisions. 
78 became one of the main supply points for the cultivation of illicit crops and drug traffickers and a strategic corridor linking the centre of the country with the mobility of both guerrillas and paramilitaries. Despite the signing of the Peace Agreements, this territory has been the "anti-drug war" laboratory since 1998, which increased the military presence in ancestral territories. The most recent phase of territorial destruction has to do with the awarding of tenders to national and transnational companies for the exploration and exploitation of hydrocarbons, mining, agro-industry and the development of major roads, such as the arteries of the project of the Initiative for the Integration of Regional Infrastructure in South America (IIRSA), in particular, the "Tumaco-Puerto AsísBelém do Pará Multimodal Corridor".

Longstanding social, political, and economic processes systematically demonstrate the illegitimate intrusion, expropriation of collective territories, violation of self-determination, implementation of ethnocidal actions and policies, and intervention or inappropriate action by the state that have threatened the physical and cultural survival of these peoples. Moreover, these interventions produced a discontinuity of space-time, a rupture of the ritual cycles used to make cosmic balance and harmony possible. The exploitation of the rubber (the weeping tree), the disrespect of the coca leaf and the bowels of the earth are a complex continuum of the politics of death that have dispossessed indigenous collectives of their collective territories and their roles as guardians and spiritual authorities, the erasure of their cultural expressions. For the peoples of the Amazon, the idea of "peace" lies in the harmony of body and territory is to listen to the sound of water and animals. The song of the forest is the song of the wise elders when it is time to mambear to purify and heal. Peace is in tobacco, in the talking circles and in the encounter with others.

From the perspective of Amazonian women, therefore, a genuine process of reconciliation and reparation in indigenous communities must start from the fires and bonfires lit in the malocas, from a cultural and collective reparation born from the women of sweet cassava, tobacco and ambil (Coordinación de Mujer, Niñez y Familia de la OPIAC, 2015b: 56).

\section{The Body As The Primary Territory}

When Amazonian women propose to understand the conflict from the dimension of the body, they explain it from different perspectives.

In the cosmovision of indigenous peoples, women's bodies are an extension of the earth (Cabnal, 2010). They are, in other words, the embodiment of fertility, nurture, and nourishment. Especially among Amazonian peoples, their cosmologies present women under the figure of the sweet yucca:

The sweet yucca is a symbol, it is the word of knowledge, the scientific word, the word that gives life, the word that never destroys but builds up, it is the word that sweetens everything bitter. It is the ultimate word of knowledge and life representing the indigenous woman (wise elderly woman, 2015). 
Women also take on various roles related to the maintenance of the chagras and the use of the collective hearths (where the cooking of food, the gathering with other women, and learning for the next generations occur). Although they are care work and part of the sexual division of labour, these spaces represent the beginning of life and are scenarios of knowledge as well, so the importance of women to the community has to do with the fact that they are the first in teaching and transmit knowledge.

Given this symbolic aspect and the cultural and life-sustaining role played by women, the claim to understand the body as the first territory is an exercise in resistance to the gender-based violence that takes place in the community, the armed conflict, militarization and occupation of ancestral territories, and the extractivist economies all of them as particular violent processes. This explains "the clear and deep relationship between militarism, environmental destruction and sexism" (Puleo, 2005: 123). Gender-based violence manifests itself as damage to the individuality of the self. Sexual violence as a weapon of war, other forms of victimisation that are gendered marked (nudity and punishment in public, domestic slavery) and femicide, as mechanisms of male domination embedded in racism, ethnocide and structural violence. Those are also continuously harmful practices because:

They break the meanings that the subject attributed to her own body and a process of "alienation" from the body. Many women have expressed the sensation of "feeling in a strange body" and guilt. There is a rupture with the perception of herself and how she feels in the world, but with the estrangement, there is a difficulty to name the violent act and talk about it in public" (Coordinación de Mujer, Niñez y Familia de la OPIAC, 2015a: 39).

Besides, gender-based violence produced in these different scenarios constitutes an individual harm with collective implications, as it undermines cultural identity and imposes gender regimes that threaten principles of complementarity:

We were told that there was no machismo in indigenous communities; all work was integral. However, after the wars, the conquests, the bonanzas, that dynamic has changed. So, the new generation has the problem of saying: "Women are there to give birth", "women are there just to cook", "women are there just to be in the chagras". So, when I look at the history of nineteen hundred in the Colombian-Peruvian conflict with the rubber companies in the Amazon, machismo came up, the elders told me. After that, because they were already orphans who were raised in the orphanage, there was a total rupture, and that is why we talk about machismo today. When I went to the jungle to investigate and ask if there was this kind of machismo, we women had our roles, and so did they, but the men did not discriminate at any time (interview with wise elder woman, 2017).

With these clarifications, it can be understood that Amazonian indigenous women have emphasised the spiritual dimension as an integral dimension of what it means to be an indigenous subject when it comes to body-land-identity relations. This metaphorical identification of land and spirituality allows us to 
recognise how any act of aggression against the land is perceived as aggression against women: undermining peoples' autonomy and self-determination. This explains why the body has special importance as the first territory of defence in the recovery of the body's memory and politicisation. That is why women have undertaken an essential process of self-healing and re-signification to escape appropriation. It also shows that indigenous women, as guardians of Mother Earth, are at the forefront of the struggles to defend the territory.

\section{CONCLUSIONS}

A decolonial approach, as proposed by the indigenous women of the OPIAC process, shows the interlinkage and complexity of the power relations in which indigenous peoples find themselves even after the signing of the Havana Peace Accords. In this sense, although a political opening to listen to other voices, the post-conflict scenario shows that there continues to be a historical silence of violent ethnocidal and epistemicidal structures neglected by liberal and elitist approaches to peace need to be addressed. This refers to development models based on extractive economies, the intrusion of armed groups and drug trafficking into ancestral territories, and patriarchal logics that threaten women's bodies and lives, shedding light on the territorial and multidimensional aspects of violence.

However, the holistic understandings that a relational ontology of OPIAC women proposes not only configure a particular insight of what conflict and peacebuilding entail from territorial and local standpoints but are also discourses that challenge limited anthropocentric approaches and allow to engage resistances from subalternity and the margins of the coloniality of the nation-state. When the OPIAC process embraces a decolonial shift on peace and conflict, it claims to disrupt the hegemonic representations that have categorised them as traditional, exotic and pre-modern "others" and, on the contrary, recognises their capacities and political engagement. The latter is noteworthy because OPIAC's women's process is a reflective and critical scenario (externally and internally), allowing for identifying internal violence and machismo and the reinterpretation of women's place and value within their collectives.

It is also relevant how participants foregrounded the need for collective healing, historical memory, returning to their cultural frameworks, to the chagras, to the malocas, rebuilding as a people. This is something that many communities have not been able to do in the context of forced displacement and recent armed confrontations within their territories in the current post-conflict scenario. The latter requires that the "ethnic approach" that institutions have used allows for alternatives to the psychosocial approach that include other non-Western, feminist, and caring dimensions of healing. What is needed, then, is not only transformative dialogue to "include" alternative perspectives but also concrete and urgent actions today.

Finally, the epistemology of cuerpo-territorio is aimed in this direction. From this insight, conflict can be understood as a damage to individuality, 
the collective, and the territory, causing imbalances in spiritual harmony and the cosmos. The spiritual dimension is an element that complements feminist ideas about embodiment (the sensory dimension, the lived experience). In this case, the spirituality underpinned by indigenous women is not transcendental but based on symbolic and material claims, as spirituality is only possible with the existence of conditions to live in the ancestral territory, guarantee food sovereignty and develop as a people. This epistemology is about resistance and struggles for existence.

Diana Paola Garcés Amaya is a PhD candidate in Migration Studies at the University of Granada (Spain). In her dissertation she analyses the official narratives and legal treatment of asylum claims based on gender grounds in Spain, examining how race, nation and gender are intertwined as devices to exclude applicants from membership. She holds a MA in Gender
Studies and a MA in Human Rights. She has been research assistant in the School of Gender Studies at the National University of Colombia, and national consultant for issues including gender-based violence in armed conflict, gender and access to land, and the social movement of indigenous Amazonian women. <https://orcid.org/0000-0001-65590783>

\section{References}

Anzaldúa, Gloria (1989). Boderlands/ La frontera. The New Mestiza. San Francisco: Aunt Lute Books.

Björkdahl, Annika and Höglund, Kristine (2013). "Precarious Peacebuilding: Friction in Global-Local Encounters". Peacebuilding, 1(3), pp. 289-299. <https://doi.org/10.1080/216472 59.2013.813170>.

Blázquez, Norma (2010). "Epistemología feminista: Temas centrales". In: Blázquez, N.; Flórez, F., and Ríos, M. (eds.). Investigación feminista: Epistemología, metodología y representaciones sociales. México DF: Centro de Investigaciones Interdisciplinarias en Ciencias y Humanidades Universidad Nacional Autónoma de México, pp. 21-29.

Cabnal, Lorena (2010). Feminismos diversos: El feminismo comunitario. Ciudad de Guatemala: ACSUR-Las Segovias.
Coordinación de Mujer, Niñez y Familia de la OPIAC (2015a). Diagnóstico sobre las afectaciones y las formas de la violencia sexual en el cuerpo y la vida de las mujeres indígenas amazónicas. Texto inédito. Bogotá, Colombia: Coordinación de Mujer, Niñez y Familia- OIM.

-. (2015b). Sistematización de la experiencia: Proceso de sanación espiritual. Texto inédito. Bogotá, Colombia: Coordinación de Mujer, Niñez y Familia-ACNUR.

Díaz, Dora (2012). "Mujeres, paz y organización de las Naciones Unidas: Contexto histórico". In: Díaz, D.; Prieto, P. Zabala, N., and Ortega, M. (ed.). Mujeres, Paz y Seguridad. Destejiendo la Guerra, Tejiendo la Paz. Bogotá DC: Impresol Ediciones, pp. 25-36.

Escobar, A.; Álvarez, S., and Dagnino, Evalgelina (2001). Política cultural y cultura política. 
Una nueva mirada sobre los movimientos sociales latinoamericanos. Madrid: Taurus-Icanh.

Femenías, María L. (2011). "Pacifismo, feminismo y utopía". Revista Internacional de Filosofía, 4(5), pp. 45-58.

Fundación Paz y Reconciliación (2014). Departamento de Putumayo. Bogotá DC: Red Prodepaz.

Gargallo, Francesca (2012). Feminismos desde AbyaYala. Ideas y proposiciones de las mujeres de 607 pueblos de nuestra América. Ciudad de México: Desde Abajo.

Gordon, E.; Cleland, Anthony, and Roos, E. (2015). "Security Sector Reform and the Paradoxical Tension Between Local Ownership and Gender Equality". Stability, 4(1), pp. 1-23. $<$ http://doi.org/10.5334/sta.gj>.

Haesbaert, Rogerio (2020). "Del cuerpo-territorio al territorio-cuerpo (de la Tierra): Contribuciones decoloniales". Cultura y Representaciones Sociales, 15(29), pp. 267-299.

Lugones, María (2008). "Colonialidad y género". Tabula Rasa, 9, pp. 73-101. <https:// doi.org/10.25058/20112742.340>.

Mac, Roger (2010). "Hybrid Peace: The Interaction Between Top-Down and Bottom-Up Peace". Security Dialogue, 41(4), pp. 391-412. <https://doi.org/10.1177/0967010610374312>.

-. (2015). "Where Is the Local? Critical Localism and Peacebuilding". Third World Quarterly, 36(5), pp. 840-856. <https://doi.org/ 10.1080/01436597.2015.1045482>.

Marchese, Giulia (2019) "From the Body in Territory to the Body-Territory: Elements Towards a Latinamerican Feminist Genealogy of the Critique of Violence". Entrediversidades, 6(2), pp. 39-72.

McLeod, Laura and O'Reilly, Maria (2019). "Critical Peace and Conflict Studies: Feminist Interventions". Peacebuilding, 7(2), pp. 127145. <https://doi.org/10.1080/21647259.2019. $1588457>$.

Mirón, Dolores (2009). "Mujeres en pie de paz. Pensamiento y prácticas". Revista de la Paz y los Conflictos, 2, pp. 133-134.
Púa, Franklin (2010). "Mito y ética: Una lectura del pensamiento mítico de los Uitoto y Muinane". Franciscanum, 52(154), pp. 115-149.

Puleo, Alicia (2005). "Del ecofeminismo clásico al deconstructivo: Principales corrientes de un pensamiento poco conocido". In: Amorós, Celia and Miguel, Ana de (ed.). Teoría feminista. De la Ilustración a la globalización. Madrid: Minerva.

Quijano, Anibal (2000). "Coloniality of Power, Eurocentrism, and Latin America". Nepantla, 1(3), pp. 533-580. <https://doi.org /10.1177/0268580900015002005>

Reardon, Betty (2010). "La problemática del patriarcado: Hacia una teoría de género de la violencia global". In: Díez, María and Sánchez, Margarita (eds). Género y paz. Barcelona: Icaria, pp. 219-260.

Rodríguez, Ana (2019). “A Decolonial Critique of the Liberal Peace: Insights from Peace Practices of Ethnic People in Colombia". Revista de la Paz y los Conflictos, 12(2), pp. 199-223. <https://doi.org/10.30827/revpaz.v12i2.9379>.

Rodríguez, Laura (2020) “'We Are Not Poor Things': Territorio Cuerpo-Tierra and Colombian Women's Organised Struggles". Feminsit Theory, March, n. p. <https://doi. org/10.1177/1464700120909508>.

Sabaratnam, Meera (2013). "Avatars of Eurocentrism in the Critique of the Liberal Peace". Security Dialogue, 44(3), pp. 259-278. <https:// doi.org/10.1177/0967010613485870>.

Santos, Milton (2000). La naturaleza del espacio técnica y tiempo. Razón y emoción. Madrid: Ariel.

Sweet, Elizabeth and Ortiz, Sara (2017). "Engaging Territorio Cuerpo-Tierra Through Body and Community Mapping. A Methodology for Making Communities Safer". Gender, Place and Culture, 24(4), pp. 594-606. <https:// doi.org/10.1080/0966369X.2016.1219325>.

Tarrow, Sidney (2004). El poder en movimiento. Los movimientos sociales, la acción colectiva y la política. Madrid: Alianza. 
WHEN THE FOREST DOES NOT SING ANYMORE. CUERPO-TERRITORIO APPROACH OF AMAZONIAN INDIGENOUS...

Young, Iris (1990). Justice and the Politics of nist Geographical Method for the Study of EmDifference. Princeton: Princeton University Press. bodiment". Annals of the American Association (2020). “Cuerpo-Territorio: A Decolonial Femi- doi.org/10.1080/24694452.2020.1812370>. 